A Final Progress Report

Contract No. DE-FGO2-96NE381.54

\title{
PARTICIPATION IN THE U.S. DEPARTMENT OF ENERGY REACTOR SIIARING PROGRAM
}

\section{OCTOBER 1996 - SEPTEMBER 1997}

\author{
Submitted to: \\ John Gutteridge \\ U.S. Department of Energy \\ Office of Nuclear Energy, Science and Technology \\ Office of Planning and Analysis, NE-20 \\ Germantown, MD 20874 \\ Submitted by: \\ R.U. Mulder \\ Director of Reactor Facility and Associate Professor \\ P.E. Benneche

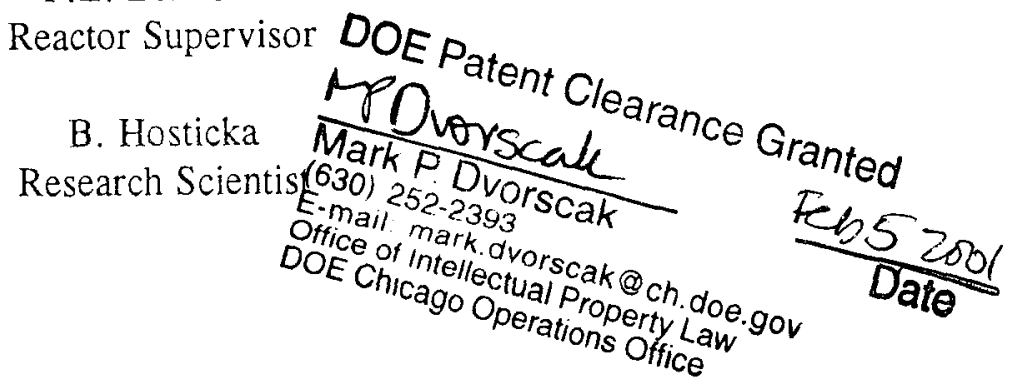 \\ Department of Mechanical, Aerospace and Nuclear Engineering \\ School of Engineering and Applied Science \\ University of Virginia \\ Charlottesville, Virginia 22903
}

Proposal No. MANE-DOE/__ _ -

Copy No.

April 1998 


\section{DISCLAIMER}

This report was prepared as an account of work sponsored by an agency of the United States Government. Neither the United States Government por any agency thereof, nor any of their employees, makes any warranty, express or implied, or assumes any legal liability or responsibility for the accuracy, completeness, or usefulness of any information, apparatus, product, or process disclosed, or represents that its use would not infringe privately owned rights. Reference herein to any specific commercial product, process, or service by trade name, trademark, manufacturer, or otherwise does not necessarily constitute or imply its endorsement, recommendation, or favoring by the United States Government or any agency thereof. The views and opinions of authors expressed herein do not necessarily state or reflect those of the United States Government or any agency thereof. 


\section{DISCLAIMER}

Portions of this document may be illegible in electronic image products. Images are produced from the best available original document. 
I. CONTRACTUAL INFORMATION $\ldots \ldots \ldots \ldots \ldots \ldots$

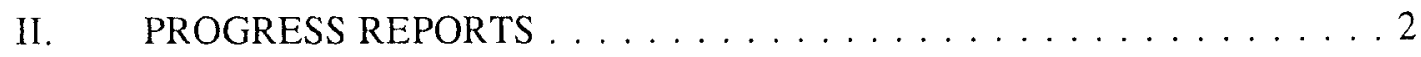
FINAL PROGRESS REPORT, Oct. 1996 - Sep. 1997

A. Introduction $\ldots \ldots \ldots \ldots \ldots \ldots \ldots \ldots \ldots \ldots \ldots$

B. Summary of Objectives and Previous

Participation in the DOE Reactor Sharing Program . . . . . . . . 2

B.1 Tours by Colleges and Primary/Secondary Schools . . . . . . 3

B.2 Student Participation in Experiments . . . . . . . . . 3

B.3. Academic Research Projects Conducted at UVA . . . . . . . 4

B.4. Irradiation Services Offered to User Institutions . . . . . . 6

C. Financial Report . . . . . . . . . . . . . 6

Table 1: Summary of Participation, 10/1/96 - 9/29/97 . . . . . . 7

Table 2: Summary of Participation, 9/1/78 - 9/29/97 . . . . . . . 8

Table 3: Experiments Performed . . . . . . . . . . 9 


\section{SECTION I}

\section{CONTRACTUAL INFORMATION}

Title: Participation in the U.S. Department of Energy Reactor Sharing Program

Submitted to:

Submitted by:

Project Director:

Duration:

Funds granted:

Type of Business:

Liaison:
John Gutteridge

U.S. Department of Energy

Office of Nuclear Energy, Science and Technology

Office of Planning and Analysis, NE-20

Washington, D.C. 20585

Dept. of Mechanical, Aerospace and Nuclear Engineering School of Engineering and Applied Science University of Virginia, Thornton Hall

Charlottesville, Virginia 22903

R.U. Mulder

Director of Reactor Facility and Associate Professor

October 1, 1996 through September 29, 1997

$\$ 8,000$

Educational Institution

All administrative communications should be addressed to:

Mr. William J. Thurneck, Jr.

School of Engineering and Applied Science

University of Virginia, Thornton Hall

Charlottesville, VA 22903

Telephone: 804/924-3155

Mr. D. Wayne Jennings, Director

Office of Sponsored programs

University of Virginia, Carruthers Hall

P.O. Box 9003

Charlottesville, VA 22906

Telephone: $804 / 924-4270$ 


\section{SECTION II}

FINAL PROGRESS REPORT

Oct. 1, 1996 - Sep. 29, 1997

\section{A. INTRODUCTION}

The University of Virginia Reactor Facility is an integral part of the Department of Mechanical, Aerospace and Nuclear Engineering. As such, it is effectively used to support educational programs in engineering and science at the University of Virginia as well as those at other area colleges and universities. The expansion of support to educational programs in the mideast region is a major objective.

\section{B. SUMMARY OF OBIIECTIVES AND UVA'S PARTICIPATION IN DOE'S REACTOR SHARING PROGRAM}

The objective of the DOE supported Reactor Sharing Program is to increase the availability of university nuclear reactor facilities to non-reactor-owning educational institutions. The educational and research programs of these user institutions is enhanced by the use of the nuclear facilities.

Several methods have been used by the UVA Reactor Facility to achieve this objective. First, many college and secondary school groups toured the Reactor Facility and viewed the UVAR reactor and associated experimental facilities. Second, advanced undergraduate and graduate classes from area colleges and universities visited the facility to perform experiments in nuclear engineering and physics which would not be possible at the user institution. Third, irradiation and analysis services at the Facility have been made available for research by faculty and students from user institutions. Fourth, some institutions have received activated material from UVA for use at their institutions. These areas are discussed below. 


\section{B.1. TQURS BY COLLEGES AND PRIMARY/SECONDARY SCHOOLS}

By far the most popular activity offered under the Reactor Sharing Program at UVA are tours of the reactor facility and associated laboratories. Many groups, either because of a lack of available time or a lack of the necessary background, do not desire to perform experiments but are most interested in a one to two hour tour. Much useful information can be conveyed during this time period and for many students this may be their only exposure to the research uses of nuclear fission.

\section{B.2. STUDENT PARTICIPATION IN EXPERIMENTS}

A part of the Reactor Sharing Program involves groups of students visiting the Reactor Facility as part of a tour and performing experiments involving the reactor or the use of radioisotopes. Over 1000 students have participated in these activities. A summary of all the colleges and universities that have participated in tours and laboratories as part of the Reactor Sharing Program is provided in Table 2.

The most common experiments fall into three general areas. These are: Radiation and Radioactive Decay; Radioisotope Applications in Science and Industry; and Reactor Operations. A brief description of several of the available experiments is provided in Table 3. In addition, special experiments can be arranged to meet the needs of classes in biology, chemistry, physics, and other disciplines.

The use of neutron activation analysis for identification of the elemental composition of materials continues to be the most popular experiment. This is a result of the wide application of neutron activation analysis for research in many areas of science. In addition to learning how to use neutron activation analysis, the students also increase their 
understanding of radioactive decay and interaction of radiation with matter.

The second most requested experiment involves measurements of the decay of

radioactive isotopes. The half-life of various short-lived reactor produced isotopes, such as aluminum-28 and magnesium-27, can be determined. Also, the decay of one isotope into another radioactive isotope is measured, to demonstrate the concept of decay chains.

The University of Virginia supplies background information to the course instructors who use the material to prepare the students for a visit to the Reactor Facility. Once at the Reactor Facility, the students perform experiments under the direction of a reactor staff member or a faculty member.

Most faculty members and students participating in these experiments have stated that they were an important addition to their classes. The positive impact of these experiments is also indicated by the number of classes making repeat visits. Table 1 gives a listing of participants in the program for 1996-1997 and Table 2 shows those institutions that have participated in the program throughout its history at the University of Virginia.

\section{B.3. ACADEMIC RESEARCH PROJECTS CONDUCTED AT UVA}

Another objective of the Reactor Sharing Program is to offer the UVAR nuclear reactor and counting facilities for general use in research projects. For example, some experiments are being performed to determine the effects of radiation on materials. However, the major use is in the area of neutron activation analysis (NAA).

Neutron activation analysis is a method of determining the elemental composition of a sample by placing it in the neutron flux of a nuclear research reactor. The neutrons interact with elements in the sample, transforming a small fraction of these into radioactive 
isotopes. The quantity of isotopes produced is governed by the amount of each element present in the sample, the level of the neutron flux, and the irradiation time.

Once produced, each radioisotope emits characteristic gamma-rays, by which the elements in the sample can be identified. When the sample is "counted", using sensitive solid state radiation detectors, the amount of each radioactive element present can be determined precisely.

At the University of Virginia we are currently able to analyze samples for over 50 different elements. This analysis is expedited by the use of dedicated computers which calculate the elemental composition directly from the gamma-ray spectra, sample mass and irradiation conditions.

Over the last eighteen years, many professors and students from various universities have carried out research projects utilizing the Reactor Facility. In most cases, the experimenters are not familiar with activation analysis techniques and depend on the reactor staff for advice on sample preparation, NAA procedures, data reduction and analysis. In a number of instances samples are supplied to the staff by the experimenters in bulk form. Starting from this, the entire analysis procedure is done by one or more staff members. The results returned to the experimenters state the elemental concentrations found in the supplied samples. This year, an undergraduate student from New York University spent about half the summer at the Reactor Facility learning, and then using, neutron activation analysis techniques in his research. This was the only major research project completed this year and is listed in Table 1 along with the other work completed. 


\section{B.4. IRRADIATION SERVICES OFFERED TO USER INSTITUTIONS}

Commonly, researchers from outside institutions request that their materials be irradiated at UVA, either with neutrons or gamma-rays. These materials are then shipped to their institutions for analysis or use. Materials activated with neutrons are either analyzed on gamma-ray spectrographic equipment or the emitted radiation used in various experiments. The UVA cobalt-60 gamma-ray irradiation facilities can be used for sterilization, inducing mutation of biological materials, or to study the effect of high doses of radiation, which can result in changes in electronic component characteristics and the cross-linking of polymers. Gamma-ray irradiation of seeds, for investigation of radiationinduced genetic mutations, continues to be a popular high school science activity. Those using these services during the contract year are listed in Table 1.

\section{FINANCIAL REPORT}

As noted in the most recent proposal, the charges for services provided under the Reactor Sharing Program were based on the number of hours of reactor operation required, at the established use charge of $\$ 100.00$ per hour of exclusive use. Other facility charges include those for use of irradiation facilities and counting equipment.

Personnel charges for the research scientist responsible for conducting the program for the period from October 1996 through September 1997 of the totaled \$6,242.40. Direct charges for reactor and laboratory use totaled $\$ 2,875.00$. No charges were made against the program account for reports and mailings. The total charged against the Reactor Sharing account (both this year's new funds and funds carried over from previous years) for services rendered during the 1996-97 contract year was $\$ 9,117.40$. 
TABLE 1

\section{SUMMARY OF REACTOR SHARING PARTICIPATION \\ October 1, 1996 to September 29, 1997}

$\begin{array}{llll}\text { University } & : \text { Univ. of Virginia } & \text { Location } & : \text { Charlottesville, Virginia } \\ \text { Program Director } & : \text { Dr. Robert Mulder } & \text { Telephone No. } & : \text { (804) 982-5440 } \\ \text { Grant Number } & : \text { DE-FG05-92ER75813 } & \text { Reactor Type } & : \text { 2 MW Pool Reactor (UVAR) }\end{array}$

\begin{tabular}{|c|c|c|c|c|c|c|}
\hline Date & Participating Institution & Instructor & Grade & $\begin{array}{l}\text { Student/ } \\
\text { Teachers }\end{array}$ & Program Description & $\begin{array}{r}\text { Direct } \\
\text { Cost } \\
\end{array}$ \\
\hline & COLLEGES & & & & & \\
\hline $11 / 15 / 96$ & Lynchburg College & N. Summerlin & UGS & $5 / 1$ & Facility tour \& laboratory & 50.00 \\
\hline Summer 97 & New York University & M. McCann & UGS & $1 / 0$ & $\begin{array}{l}\text { Neutron activation analysis of } \\
\text { many different phosphorescent } \\
\text { minerals to investigate whether } \\
\text { or not the levels of trace impurit } \\
\text { can be related to the degree of } \\
\text { phosphorescence or the color. }\end{array}$ & $2,625.00$ \\
\hline
\end{tabular}

SUBTOTAL

$6 / 1$

$2,675.00$

PRIMARY/SECONDARY SCHOOLS

$\begin{array}{ll}\text { 10/17/96 } & \text { Charlottesville High School } \\ \text { 10/25/96 } & \text { Charlottesville High School } \\ \text { Nov. 96 } & \text { Oakton High School } \\ 11 / 15 / 96 & \text { Charlottesville High School } \\ 11 / 21 / 96 & \text { King Geoge High School } \\ 12 / 11 / 96 & \text { St. Anne's - Belfield } \\ 12 / 19 / 96 & \text { St. Anne's - Belfield } \\ 01 / 13 / 97 & \text { Jack Jouett Middle School } \\ 01 / 16 / 97 & \text { St. Anne's - Belfield } \\ \text { Fcb. 97 } & \text { Honaker High School } \\ 03 / 01 / 97 & \text { Boy Scout Troop } \\ 03 / 18 / 97 & \text { Little Keswick School } \\ 04 / 22 / 97 & \text { Albemarle High School } \\ 04 / 23 / 97 & \text { Albemarle High School } \\ 04 / 24 / 97 & \text { Albemarle High School } \\ 05 / 20 / 97 & \text { Woodberry Forest School } \\ 05 / 28 / 97 & \text { Tandem Friends School } \\ 06 / 02 / 97 & \text { Sharon Elementary School } \\ 06 / 26 / 97 & \text { mixed elementary school } \\ \text { Jun. 97 } & \text { Summer teachers class } \\ & \end{array}$

E. Sturgill

PCS

$19 / 2$

Facility tour \& laboratory

50.00

E. Sturgill PCS

K. Davis PCS

$21 / 3$

Facility tour \& laboratory

50.00

E. Sturgill PCS

$1 / 0$

Gamma-ray irradiation of seeds

0.00

H. Black PCS

$9 / 3$

Elizabeth Kutchai PCS

M.V. Liew PCS

$27 / 5$

Facility tour \& laboratory

50.00

$15 / 1$

Facility tour

Facility tour

0.00

$29 / 3$

Carla Myrle PCS

Facility tour (2 groups)

0.00

$32 / 2$

Elizabeth Kutchai PCS

K. Stilwell PCS

Bruce Sullivan PCS

$13 / 1$

$0 / 1$

Aaron Parsons PCS

Dave Ridenour PCS

$15 / 13$

$8 / 2$

PCS

Dave Ridenour PCS

$32 / 2$

$38 / 2$

$28 / 4$

Paul Vickers

PCS

Lisa Beazell PCS

Dave Peters

PCS

$4 / 1$

Facility tour (2 groups)

0.00

Facility tour

Gamma-ray irradiation of seeds

Facility tour

Facility tour

Facility tour \& laboratory

Facility tour \& laboratory

Facility tour \& laboratory

Facility tour

Facility tour

Facility tour

Facility tour

0.00

0.00

0.00

0.00

$4 / 1$

$21 / 4$

Staff

PCS

$0 / 27$ analysis lab for group of high school and middle school teachers.

0.00

0.00

0.00

0.00

0.00

50.00

SUBTOTAL

$378 / 84$

200.00

TOTAL

$2,875.00$

SUMMARY

Faculty

Graduate students (GS):

Undergraduate students (UGS):

Pre-college students (PCS):

Total:

\begin{tabular}{cr} 
Groups & Students \\
\hline 0 & 0 \\
0 & 0 \\
2 & 6 \\
$\frac{20}{22}$ & $\frac{378}{384}$
\end{tabular}

Teachers/Adults

0
0
1
$\frac{84}{85}$


TABLE 2

Summary of Participation in Laboratories, Projects and Tours Under the Auspices of the Reactor Sharing Program

(September 1978 - September 1997)

University or College

Bridgewater College

Emory \& Henry College

George Mason University

Hampton University

James Madison University

J.S. Reynolds Comm. College

Longwood College

Lynchburg College

Mary Washington College

Piedmont Va. Comm. College

Randolph Macon College

Randolph Macon Women's College

Roanoke College

Rutgers University

Rutgers University

Shepherd College

S.W. Va. Community College

Sweetbriar College

University of Richmond

University of Houston

Virginia Commonwealth Univ.

Virginia Military Institute

Virginia Polytechnic Institute

Washington \& Lee

College of William \& Mary
This

year Discipline

Chemistry

Physics

Physics

Physics

Physics

Physics

Physics

Physics

Physics

Nuclear Chemistry

Biology

Chemistry

Physics

Education

Archaeology

* Chemistry

Physics

Physics

Chemistry

Physics

Physics

Physics

Physics

Physics

Physics

Chem. Engr.

Civil \& Environmental Engr.

Chemistry

Chemistry

Chernistry

Physies

Physics

Civil \& Envir. Engr.

Physics

Chemistry

Chemistry

Chemistry

Physics

Psychology

Physics

Env.\&Haz.Mat.

Geology

Marine Science

\begin{tabular}{|c|c|}
\hline $\begin{array}{l}\text { Number of } \\
\text { Interactions }\end{array}$ & $\begin{array}{l}\text { Faculty } \\
\text { Contact }\end{array}$ \\
\hline 1 & J. Martin \\
\hline 2 & D. Neher \\
\hline 1 & P. Spickler \\
\hline 4 & J. Ulrich \\
\hline 1 & C. Nelson \\
\hline 2 & Physics club \\
\hline 1 & K. Han \\
\hline 9 & J. Gordon \\
\hline 1 & R. Serway \\
\hline 7 & D. Downey \\
\hline 3 & M. Gordon \\
\hline 1 & J. Martin \\
\hline 2 & L. Fawcett \\
\hline 1 & L. Banton \\
\hline 1 & B. Bates \\
\hline 20 & N. Summerlin \\
\hline 7 & R. Atalay \\
\hline 1 & G. King \\
\hline 30 & R. Bratton \\
\hline 1 & J. Wallpole \\
\hline 4 & T. Lowe \\
\hline 1 & W. Temple \\
\hline 2 & B. Mattson \\
\hline 1 & W. Baldridge \\
\hline 1 & J. Adams \\
\hline 1 & D. Berler \\
\hline 1 & I. Wojentko \\
\hline 1 & W. Crum \\
\hline 2 & R. Epling \\
\hline 8 & H. Gager \\
\hline 1 & W. Major \\
\hline 1 & M. Vineyard \\
\hline 1 & S. Garg \\
\hline 2 & S. Herr \\
\hline 2 & K. Goins \\
\hline 2 & R. Minnix \\
\hline 5 & H. Schreiber \\
\hline 2 & P. Peters \\
\hline 1 & D. Foster \\
\hline 14 & T. Parkinson \\
\hline 1 & D. Orvos \\
\hline 1 & S. Kozak \\
\hline 3 & J. Warinner \\
\hline
\end{tabular}

Notes to Table 2:

* These institutions and faculty members participated in the Reactor Sharing Program during the current and/or previous contract year.

Additionally, numerous high school groups have toured the facility and some of these have also participated in laboratory exercises. In the 1996-97 contract year, 462 primary and secondary school students and their teachers visited the reactor as part of tour groups. 
TABLE 3

EXPERIMENTS PERFORMED FOR THE UNIVERSITY OF YIRGINIA

REACTOR SHARING PROGRAM

\section{A. RADIATION AND RADIOACTIVE DECAY OF ISOTOPES}

\section{Radiation Counting Statistics}

Demonstration of the random nature of radioactive disintegrations at both low and high disintegration rates. Using a multi-scaler, series of counts are taken which, respectively, approach a Poisson distribution and a Gaussian distribution.

\section{Radioisotope Decay and Half-Life Determination}

Demonstration of radioactive decay and determination of reactor produced, short-lived isotope half-life, using a multi-scaler. More complex decay chains may also be demonstrated, such as decay of two isotopes with differing half-lives or decay of two isotopes, one of which is transformed by decay to the other.

\section{Types of Radiation}

Characterization of different types of radiation including determination of alpha- and beta-particle energy spectra, using silicon surface barrier devices, and gamma-ray spectra, using either a sodium-iodide scintillator or a germanium detector. Effectiveness of shielding materials for the various radiation types may also be demonstrated.

\section{Radiation Intensity and Shielding}

Demonstration of the decrease in radiation intensity as a function of the inverse square of distance from the radiation source. Determination of source activity from measured dose rates and radiation energy. Effectiveness of radiation shields may also be included.

\section{B. RADIOISOTOPE APPLICATIONS IN SCIENCE AND INDUSTRY}

\section{Neutron Activation Analysis}

Demonstration of trace element analysis using neutron activation analysis. A sample is activated in the UVAR and its constituents determined from the nature of its radioactive decay. Activation analysis of a coin, lipstick, hair, environmental samples, or other samples may be performed.

\section{X-Ray Fluorescence Analysis}

Demonstration of the chemical analysis of thin samples using an Am-241 xray exciter source and a germanium-lithium low-energy photon spectrometer. The $x$-ray spectrum measured from the material is used to determine the chemical composition of the surface. 
TABLE 3 (continued)

3. Industrial Applications of Radioisotopes

Demonstration of the use of radioisotopes in industrial applications, such as thickness gauging, liquid level sensing and flow detection. Beta, gamma and neutron sources are used.

\section{REACTOR EXPERIMENTS}

\section{Approach to Critical}

Demonstration of the subcritical multiplication of neutrons until a selfsustaining fission reaction is obtained.

\section{Reactor Dynamics and Safety Systems}

Demonstration of changes in reactor power resulting from control rod position changes. Calibration of control rods and demonstration of reactor safety systems.

\section{Decay Heat Following Reactor Shutdown}

Measurement of heat generation from fission and fission product decay following a reactor shutdown. Measurements are read from nuclear instrumentation and calculated from primary system heat balance. 